\title{
Editorial
}

\section{The changing phenotype of the human species (affluent variety)}

No-one could walk the streets of a city in India and fail to observe the contrast between the slender grace of its inhabitants and the massive clumsiness of the western tourists who wander among them. Nor can you spend a day watching the crowds at one of the Florida theme parks without realising that something awful is happening to our species. How did this come about? Homo sapiens is thought to have left Africa some 5000 generations ago - not very long in evolutionary time - and the people who colonised Europe 50,000 years ago probably looked very much like their modern descendants; their skeletons show that they were much the same height as ourselves. Comparison with modern hunter-gatherers suggests that their diet was reasonably adequate and varied; that their body mass index, blood pressure and cholesterol were considerably lower than ours, and that diabetes was unknown [1].

Our ancestors lived as hunter-gatherers for $99 \%$ of our evolutionary history, but the species has been through one great transition since then, and is now entering a second. The first transition occurred some 10,000 years ago as people settled in farming communities. This may have been forced upon them by increased population pressure [2], and its health consequences were adverse. In ancient Turkey, one of the places where the transition first occurred, the mean height of the earlier hunter-gatherers was $178 \mathrm{~cm}$ for men and $167.5 \mathrm{~cm}$ for women, but fell progressively to $160 \mathrm{~cm}$ for men and $155 \mathrm{~cm}$ for women in the settled communities [3]. Increased dependence upon single crops meant a less varied diet and episodic famine, a risk that persisted into recent times [4], while rising population density greatly increased ex-

Received: 24 June 2004 / Accepted: 7 July 2004

Published online: 23 July 2004

(C) Springer-Verlag 2004 posure to infectious disease. Cities were often deathtraps, such that in 1662 only one in four children born in London survived to the age of 26, while just $6 \%$ reached the age of 56 [5]. By 1840 , only $5 \%$ of Londoners were aged 60 or above, $35 \%$ were under the age of 15 , and $50 \%$ died before the age of 21 . One child in two lived past the age of 12 in the northern industrial cities of the UK [6]. As in some poor countries today, children proliferated but died easily, and old age was a rarity.

The consequences were plain to see. In 1870 , working men aged 20 to 50 who lived in my own city of Bristol had a mean height of $167 \mathrm{~cm}$ and a BMI of 21.7 [7]. We would walk among them like western tourists in India. Their growth was strongly influenced by income and social class-in 1880 the children of the rich were on average $10 \mathrm{~cm}$ taller and $3.2 \mathrm{~kg}$ heavier than the children of the poor [8] - and the well-to-do continued to grow faster than the less advantaged through most of the twentieth century. Differences between income groups proved persistent despite an all-round improvement in the standard of living, and only Scandinavia had succeeded in eliminating the growth gap in social class by the 1970s [9]. The scale of this achievement can be inferred from a 1930 survey, which showed that $25 \%$ of Swedish children shared their bed with two or more other family members, while $50 \%$ grew up in a home where four people or more slept in the same room. Iron deficiency anaemia, rickets and tuberculosis were common, and meat, vegetables and fruit were rarely eaten [10]. We in the westernised world are the beneficiaries of an extraordinary revolution in wealth, and therefore in health, that can be measured in decades.

One consequence of the wealth revolution is increased longevity, and for the first time in history most people can now expect to survive well past the age of 70. This in itself accounts for much of the rise 


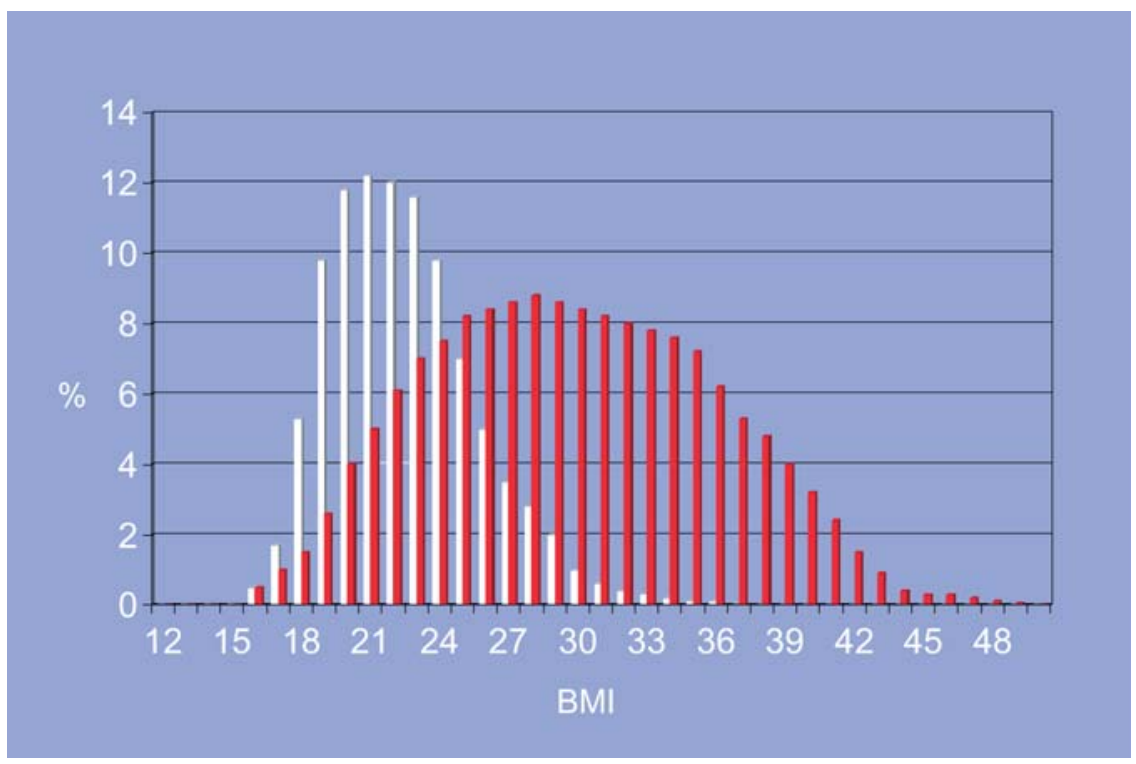

Fig. 1. The second transition: the distribution of obesity within the population is shifting away from the traditional pattern (white bars). The future distribution threatens to resemble that shown in the red bars. From Prentice [19], by permission of Oxford University Press

in prevalence of Type 2 diabetes. In America the risk of diabetes is 3.5 times greater over the age of 65 , and the proportion of people in this category increased from $8 \%$ to $12 \%$ over the second half of the twentieth century. People with diabetes also survive longer than they did, thus swelling the prevalence but not the incidence figures. It is worth noting that the number of newly diagnosed cases identified by repeated National Health Interview Surveys did not change at all between 1968 and 1992 [11]. The wealth revolution has allowed us to fulfil much of our genetic potential for growth as well as for age, and the human phenotype has responded rapidly. We grow faster, reach sexual maturity 3 to 4 years earlier than our great-grandparents (which is why adolescence is a twentieth century phenomenon), and our body proportions have changed; legs now grow longer relative to trunks and arms, resulting in the long-legged look favoured in fashion models $[12,13]$. A less welcome consequence is altered body composition with progressive accumulation of adipose tissue.

When 30 to $50 \%$ of children died from infection, undernutrition, or both (as still happens today in some parts of the world), selection for immunity and metabolic efficiency was intense. We are descended from the survivors. It is tempting to believe that genes conferring susceptibility to Type 2 diabetes are common because they carry a selective advantage in terms of the ability to survive famine. The thrifty gene hypothesis was suggested by Aschner and Post in 1957 and later elaborated by J. V. Neel $[14,15]$. His proposal was that the hypothetical gene for diabetes, like that for sickle cell disease, was in balanced polymorphism within the population. Homozygotes would develop juvenile diabetes and die, but heterozygotes would have a more efficient pattern of insulin secretion enabling them to survive famine better than the rest of the population. We can now appreciate that a single-gene model is outmoded; many genes contribute to energy metabolism and efficiency, multiple variants of these genes exist, and all have been subject to selection for thrift. The resulting metabolic diversity has an evolutionary advantage, since heterogeneity offers the best guarantee that some members of a group will survive any given environmental challenge. Seen from this perspective, it is not surprising that major genes conferring susceptibility to obesity or Type 2 diabetes are rare. Instead we encounter a complex patchwork of genetic and developmental influences upon insulin secretion, insulin resistance, fat deposition and inflammation [16].

The pioneers of diabetes genetics tended to view the body as a malfunctioning machine, on the assumption that correction of faulty genes or the pathways they controlled would restore a state of healthy normality. We now know that no population is exempt, and that different gene combinations predispose to diabetes and obesity in different ethnic groups. The implication is clear: diabetes and its co-morbidities are part of our evolutionary heritage, embedded within our thrifty genome. Genetic heterogeneity implies that responses to undernutrition and other forms of environmental stress will vary within and between populations, but we are all more or less predisposed to store adipose tissue when food is abundant. For Russell Wilder, writing in 1930, the real question was "why, then, do we not all grow fat?" [17]. The twenty-first century can only reply that given the right environment, most of us will, and that the process is far from complete (Fig. 1).

As our phenotype changes, so must our concept of normality. The Centre Court seats at Wimbledon will 
soon be $15 \%$ wider than in 1922, and Boeing has altered its airline seats to allow for a $9 \mathrm{~kg}$ increase in the mean weight of its passengers $[18,19]$. The $70 \mathrm{~kg}$ man studied by generations of medical students has become a myth, to be replaced by an $80 \mathrm{~kg}$ man with inflationary tendencies. Our concept of homeostasis will also require revision, for the "milieu intérieur" of the affluent phenotype is not constant, but reflects progressive adaptation of the internal environment to evolving and interactive changes in body weight, blood pressure, lipids, endothelial function and carbohydrate metabolism. Influenced by multiple genes and by behaviour-and therefore varying widely from one individual to the next-functional consequences will accumulate, cascade, summate, and eventually become largely irreversible. This time-dependent process of progressive internal adaptation to an affluent external environment has been referred to as "allostasis" [20]. Older physicians expressed the same idea when they said that "fat is like capital accumulating at compound interest". Our concept of normality has limited relevance to the evolving internal environment of someone with a BMI of 30 .

Where does this leave the diabetes specialist? Perhaps with the uneasy reflection that it may be possible to treat a disease, but that it is scarcely possible to treat a phenotype. Type 2 diabetes arises on the basis of age, race, heredity and obesity, and only one of these is amenable to therapy. This would not matter so much if we were any good at treating obesity, but, with gratifying exceptions, its treatment is a catalogue of failure [21]. Nor, to be honest, are diabetologists particularly effective at treating diabetes, either when it comes to achieving and maintaining our selfimposed targets for glucose control, or when it comes to demonstrating that we are able to influence the longevity of our patients by doing so. Our journals are filled with clinical trials that demonstrate the feasibility of converting very poor glucose control into control that is merely unsatisfactory. We intervene too late, and treat the consequences of the condition rather than its causes. This is not to say that diabetologists are a waste of time-there is good evidence to show that we are not-but all too often we are placed in the position of the Anglo-Danish king who sat on the beach and ordered the tide not to come in.

The shape of things to come can be discerned in a number of related developments. As the margin between diabetes and non-diabetes narrows, the American Diabetes Association has redefined the threshold for impaired fasting glucose downwards to $5.6 \mathrm{mmol} / \mathrm{l}$ [22]. The consequence, according to the authors of an article in this issue of the journal, is to create a pandemic of diabetes [23]. Is this new definition a form of diagnostic imperialism, designed to annex even more clinical territory for our speciality? A pre-emptive strike against those cardiologists who seek to redefine diabetes as a vascular disease? Or a useful spur to earlier diagnosis and intervention? The likelihood is that this half-way measure will satisfy nobody. Clinicians will prefer the higher glucose threshold used to define those members of the population for whom traditional palliative care for diabetes is appropriate, while those interested in disease prevention will feel unsatisfied. They can argue that even $5.6 \mathrm{mmol} / \mathrm{l} \mathrm{rep}-$ resents a major deviation from normal glucose balance, that its rationale in terms of disease prediction or intervention is unproved, and that an isolated measurement of fasting glucose is inadequate to identify the at-risk phenotype [24].

When a whole population is at risk, it becomes logical to treat the whole population. Two British epidemiologists have published a thought experiment in which they envisage the benefits of treating all adults over the age of 55 with a combined pill containing a statin, three antihypertensive agents, aspirin and folic acid [25]. Ridiculous? No, logical. If we are all at risk, we would all benefit from treatment. It is-from the perspective of the two epidemiologists - the traditional "screen and treat" strategy that lacks logic. Screening, as they point out, cannot discriminate cleanly between risk and non-risk, for the simple reason that the whole population falls within the risk category. The proposal needs testing but the logic seems impeccable, and-who knows?-one day an insulin sensitiser might become an ingredient of the polypill.

Our species has seen two great transitions. The first transition came with the introduction of agriculture, which resulted in increased population density, intermittent undernutrition and much greater exposure to epidemic and water-borne infection. Selection pressure was at its most intense under the age of five. The second transition, less than a century old, brought freedom from hunger and most forms of infectious disease. This, the greatest benefit ever to be experienced by the human race, is already taken for granted. The second transition remains incomplete, for its full effects have only been felt by the relatively affluent, and its consequences upon their physique and health have yet to be fully expressed. Meanwhile, like it or loathe it, the changing phenotype of our species will change our whole perception of health. Many might wish to lead a "more natural" life, but this is nostalgia for what never was. Our species domesticated itself long ago, together with its farm animals, and wildtype humans are virtually extinct. We have made our own environment and must learn to live in it.

One implication is that we can turn our remarkable developmental plasticity to our own advantage. There are indications of hope. Adult height can be predicted with reasonable accuracy from a child's height at age 3 , but adult obesity is less easily predicted from its weight; parental obesity is more of a risk factor [26]. Equally, height has increased in linear fashion in response to greater wealth [27], but obesity has a much more complex relationship with affluence, and there 
are striking differences between and within populations. In western countries the better educated and better off are less likely to gain weight than the relatively deprived. All this suggests that we can remodel the adult phenotype of future generations, but with the proviso that the war must be fought and won in the nursery and in the infant school. Failing this, pharmaceuticals will increasingly form part of our routine survival kit for life on planet Earth. Unless, of course, the privileged minority of its inhabitants who have experienced the wealth revolution fails to find a way of sharing its benefits peacefully with the rest, for war and famine are very effective remedies for diabetes.

\section{E. A. M. Gale}

Diabetes and Metabolism, Medical School Unit, South-mead Hospital, Bristol, UK

\section{References}

1. Eaton SB, Konner MJ (1985) Paleolithic nutrition: a consideration of its nature and current implications. New Engl J Med 312:283-289

2. Cohen MN (1977) The food crisis in prehistory. Overpopulation and the origins of agriculture. Yale University Press, New Haven London

3. Diamond J (1991) The third chimpanzee. Radius, London

4. Roi Ladurie E le (1971) Times of feast, times of famine. A history of climate since the year 1000. Translated by Barbara Bray. Doubleday, New York

5. Graunt J (1996) In: Wills C (ed) Yellow fever, black goddess. The coevolution of people and plagues. Helix, Reading, Massachusetts

6. Gregory G (1840) Lecture on the statistics of mortality and diseases in London. Lancet i:79-90

7. Beddoe J (1870) On the stature and bulk of man in the British Isles. Asher and Co, London

8. Clements EMB (1953) Changes in the mean stature and weight of British children over the past seventy years. BMJ ii:896-902

9. Tanner JM (1981) A history of the study of human growth. Cambridge University Press

10. Persson LÅ, Samuelson G, Sjölin S (1989) Nutrition and health in Swedish children 1930-1980. Three nutrition surveys in a northern Swedish county. Acta Paediatrica Scand 78:865-872
11. Kenny SJ, Aubert RE, Geiss LS (1995) Prevalence and incidence of non-insulin-dependent diabetes. In: National Diabetes Data Group, Diabetes in America. NIH Publication No 95-1468, pp 47-67

12. Leitch I (1951) Growth and health. Br J Nutr 5:142-151

13. Jantz LM, Jantz RL (1999) Secular change in long bone length and proportion in the United States, 1800-1970. Am J Phys Anthropol 110:57-67

14. Aschner BM, Post RH (1957) Modern therapy and hereditary diseases. Acta Genet 6:362-369

15. Neel JV (1962) Diabetes mellitus: a "thrifty" genotype rendered detrimental by progress? Am J Hum Genet 14:353-362

16. Kahn SE, Prigeon RL, Schwartz RS et al. (2001) Obesity, body fat distribution, insulin sensitivity and islet $\beta$-cell function as explanations for metabolic diversity. J Nutr 131:354S-360S

17. Wilder RM (1930) The management of obesity. J Am Diet Assoc 6:91-100

18. Woolcock N (2004) Wimbledon stretches a point after volley of complaints. The Times, June 10th 2004

19. Prentice AM (1997) Obesity-the inevitable penalty of civilisation? Br Med Bull 53:229-237

20. Stumvoll M, Tataranni PA, Stephan N, Vozarova B, Bogardus C (2003) Glucose allostasis. Diabetes 52:903-909

21. Frank A (1993) Futility and avoidance. Medical professionals in the treatment of obesity. J Am Med Assoc 269:2132-2133

22. Expert Committee on the diagnosis and classification of diabetes mellitus (2003) Follow-up report on the diagnosis of diabetes mellitus. Diabetes Care 26:3160-3167

23. Borch-Johnsen K, Colagiuri S, Balkau B et al. (2004) Creating a pandemic of diabetes: the proposed new criteria for impaired fasting glucose. Diabetologia 47: DOI 10.1007/s00125-004-1468-6

24. Meigs JB, Villalpando CG, Williams K et al. (2004) Using metabolic syndrome traits for efficient detection of impaired glucose tolerance. Diabetes Care 27:1417-1426

25. Wald NJ, Law M (2003) A strategy to reduce cardiovascular disease by more than $80 \%$. BMJ 326:1419-1423

26. Whitaker RC, Wright JA, Pepe MS, Seidel KD, Dietz WH (1997) Predicting obesity in young adulthood from childhood and parental obesity. New Engl J Med 337:869-873

27. Steckel RH (1995) Stature and the standard of living. J Econom Lit 33:1903-1940

E. A. M. Gale (

Diabetes and Metabolism, Medical School Unit,

Southmead Hospital, Bristol, BS10 5NB, UK

E-mail: Edwin.Gale@bristol.ac.uk

Tel.: +44-117-9595337, Fax: +44-117-9595336 